\title{
Rise and Fall of the Grand Canal in the Ancient Kaifeng City of China: Role of the Grand Canal and Water Supply in Urban and Regional Development
}

\author{
Wenji Huang ${ }^{1}$, Mingwang $\mathrm{Xi}^{2}$, Shibao $\mathrm{Lu}^{1,3, *}$ and Farhad Taghizadeh-Hesary ${ }^{4, *(D)}$ \\ 1 School of Political Science and Public Administration, Neijiang Normal University, Neijiang 641112, China; \\ scdxhwj@163.com \\ 2 Department of The Commission for Discipline Inspection, Luoyang Normal University, \\ Luoyang 471934, China; hnsp0613@126.com \\ 3 College of Public Administration, Zhejiang University of Finance and Economics, Hangzhou 310018, China \\ 4 Social Science Research Institute, Tokai University, Hiratsuka-shi 259-1292, Kanagawa-ken, Japan \\ * Correspondence: lushibao@zufe.edu.cn (S.L.); farhad@tsc.u-tokai.ac.jp (F.T.-H.)
}

\section{check for}

updates

Citation: Huang, W.; Xi, M.; Lu, S.; Taghizadeh-Hesary, F. Rise and Fall of the Grand Canal in the Ancient Kaifeng City of China: Role of the Grand Canal and Water Supply in Urban and Regional Development. Water 2021, 13, 1932. https:// doi.org/10.3390/w13141932

\section{Academic Editors:}

Vasileios Tzanakakis, Giovanni De Feo and Andreas N. Angelakis

Received: 13 June 2021

Accepted: 2 July 2021

Published: 13 July 2021

Publisher's Note: MDPI stays neutral with regard to jurisdictional claims in published maps and institutional affiliations.

Copyright: (c) 2021 by the authors. Licensee MDPI, Basel, Switzerland. This article is an open access article distributed under the terms and conditions of the Creative Commons Attribution (CC BY) license (https:/ / creativecommons.org/licenses/by/ $4.0 /)$.

\begin{abstract}
In the long history of the feudal society of China, Kaifeng played a vital role. During the Northern Song Dynasty, Kaifeng became a worldwide metropolis. The important reason was that the Grand Canal, which was excavated during the Sui Dynasty, became the main transportation artery for the political and military center of the north and the economic center of the south. Furthermore, Kaifeng was located at the center of the Grand Canal, which made it the capital of the later Northern Song Dynasty. The Northern Song Dynasty was called "the canal-centered era." The development of the canal caused a series of major changes in the society of the Northern Song Dynasty that were different from the previous ones, which directly led to the transportation revolution, and in turn, promoted the commercial revolution and the urbanization of Kaifeng. The development of commerce contributed to the agricultural and money revolutions. After the Northern Song Dynasty, the political center moved to the south. During the Yuan Dynasty, the excavation of the Grand Canal made it so that water transport did not have to pass through the Central Plains. The relocation of the political center and the change in the canal route made Kaifeng lose the value of connecting the north and south, resulting in the long-time fall of the Bianhe River. Kaifeng, which had prospered for more than 100 years, declined gradually, and by the end of the Qing Dynasty, it became a common town in the Central Plains. In ancient China, the rise and fall of cities and regions were closely related to the canal, and the relationship between Kaifeng and the Grand Canal was typical. The history may provide some inspiration for the increasingly severe urban and regional sustainable development issues in contemporary times.
\end{abstract}

Keywords: Grand Canal; Kaifeng; water supply; sustainable development; city and regional development

\section{Introduction}

The evolution of the regional ecological environment is closely related to human civilization. China, India, Egypt, and Babylon (now Iraq) originated from the Yellow River, Ganges River, Nile River, and the Euphrates and Tigris Rivers, respectively. Furthermore, human civilization declined with the exhaustion of rivers; for example, the decline of ancient Egyptian civilization was closely related to the decline of the Nile River, and the cutting off of the Kongque River caused the extinction of the Loulan ancient country in China.

If natural rivers are the cradle of human civilization, canals (or artificial waterways) are the masterpieces of human civilization. Irrigation in Egypt started between 3218 BC and 3035 BC. Early Egyptians relied on river water for natural irrigation. However, due to the arid climate in most of Egypt and the growing population, natural irrigation from 
river water alone was hard to continue. Ancient Egyptians explored the use of the Nile River for artificial irrigation step by step, including partial basin irrigation and irrigation network systems, to manage irrigation water [1,2]. The Egyptian canal culture began during the reign of King Scorpion (approximately 2725-2671 BC) [3].

The southern region of Mesopotamia, which is southern Iraq now, had a close relationship with the history of water systems (2475-2315 BC), which included artificial waterways, irrigation projects, swamps, and dams (Wilkinson; 2013) [4,5], as shown in Figure 1. During Sargon's reign (2350-2150 BC), the Sumerians and Akkadians built a complex network of canals. In order to protect themselves from the periodic floods of the Tigris and Euphrates, the Sumerians continued to dredge the silt caused by the two rivers every year to maintain the canal [6].

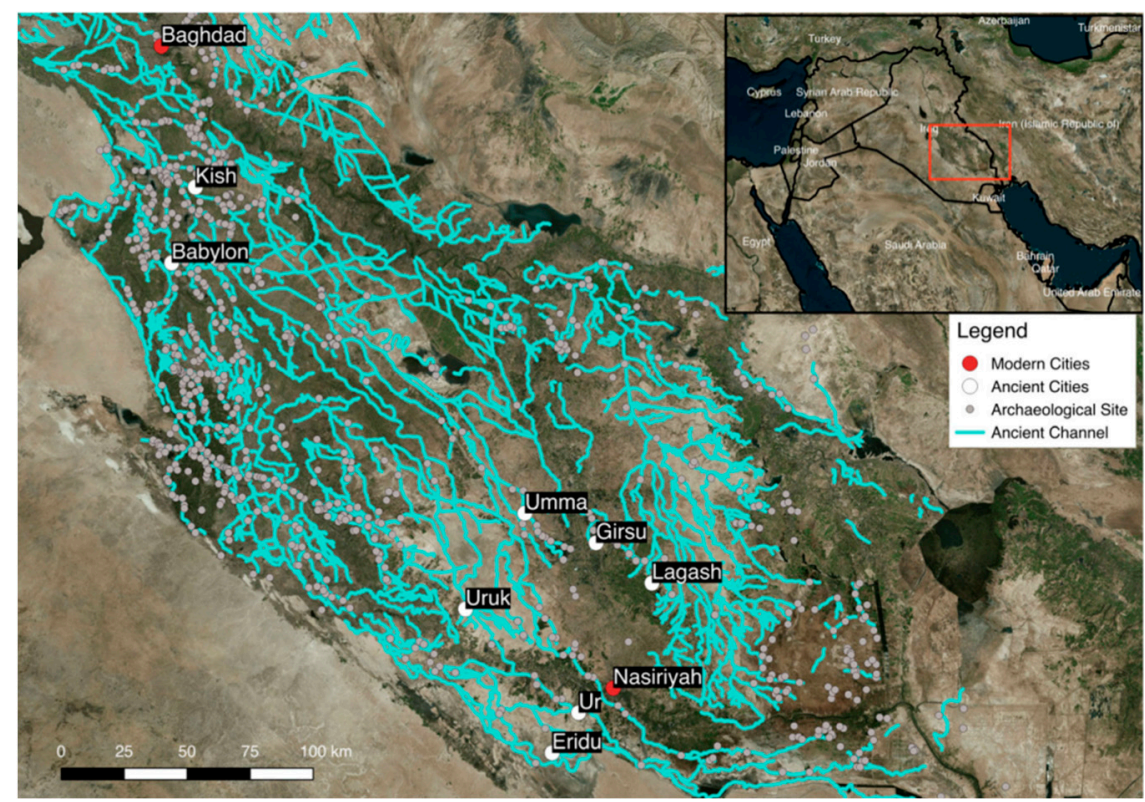

Figure 1. Map of southern Iraq, showing ancient sites and channels, along with major ancient cities. All information are taken from [4].

Like many other places in the world, Indian civilization flourished around rivers and deltas. The river is still an eternal symbol of national culture. Shaw et al. (2007) believed that the development of advanced irrigation systems in ancient India led to complex city societies and centers. The Indus Valley Civilization Complex (3000-1500 BC) was very prominent in water conservancy projects [7], as shown in Figure 2.

In the Western Hemisphere, a kind of indigenous civilization, the Norte Chico civilization, flourished from $3000 \mathrm{BC}$ to $1800 \mathrm{BC}$. This civilization was mainly composed of four valleys, namely, the Supe, Pativilka, Fortaleza, and Huaura Rivers, in the coastal areas of central and northern Peru; all these valleys share a common coastal plain known as Multipotamia. As early as 3000 BC, there were already very advanced urban centers in Multipotamia. Therefore, Sumeria may have been the only place with a similar degree of urban complexity to that of the city of Multipotamia [8].

From the above cases, we can conclude that cities are the center of human's social, economic, and cultural activities and revolutions, and maintaining the healthy and sustainable development and prosperity of cities is an important guarantee for the social and economic sustainable development of a country or region. Water resources play an important role in the rise and fall of cities and regions in the world: developed transportation and perfect water conservancy can promote the development and prosperity of a city and a region; in contrast, the loss of transportation hub status and the destruction of water conservancy facilities often lead to the decline of cities and regions. 


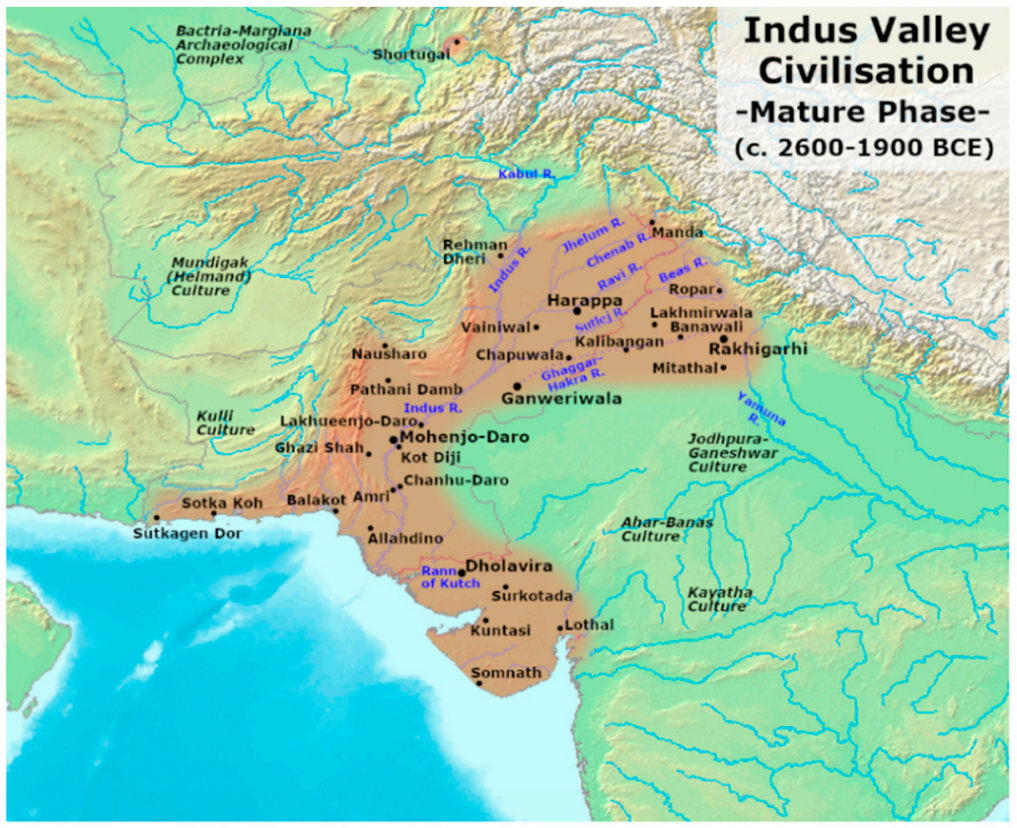

Figure 2. The geographical extent of the Indus valley civilization (source: https://commons. wikimedia.org/wiki/File:Indus_Valley_Civilization,_Mature_Phase_(2600-1900_BCE).png; accessed on 7 July 2021).

China is a large country, and there have been many river systems in the middle and eastern parts of China since time immemorial. The Grand Canal of China was dug as early as 486 BC. Before the Sui Dynasty, a few canals were already dug among water systems; however, they were not connected to each other by that time. When the Sui dynasty unified the whole country, the Emperor Yang of Sui ordered digging of the Tongji and Yongji canals and the connection of the Jiangnan canal with the Hangou canal. The grand canals in the south and the north were connected until then, and the interconnected canal was almost $2700 \mathrm{~km}$ long. It was the first time in which the national waterway transportation network was constructed for military and canal transportation purposes in China's history [9]. The water transportation network ushered in a fundamental change till the Yuan Dynasty was founded. After the Yuan Dynasty, the Jizhou and Huitong canals were dug to connect the Yellow River and the Weiyun Canal to avoid the high terrain in Shandong. Simultaneously, the Tonghui canal was dug after several twists and turns to achieve water and land transshipment. The Grand Canal from Beijing to Hangzhou was successfully dug, it was at least $1790 \mathrm{~km}$ long, and its pattern has been maintained [10]. Therefore, we can say that the Grand Canal is a human-made canal with the longest existence and longest mileage in the world. It is connected through a series of rivers and lakes in China, allowing commercial towns and agricultural irrigation along the line to develop. It flows mostly through developed regions with dense populations, active agricultural economy, industry, and commerce in China. The Grand Canal also pushes the incredible fusion of economy and culture in different regions of China. It facilitates commercial trade and cultural transmission between China and neighboring countries and regions.

Given the background mentioned above and the importance of the topic, this research aimed to provide an enhanced study on the relations between the rise and fall of China's canals and cities during the 6th-12th centuries. It aims to provide policy implications for boosting urban and regional sustainable development.

\section{Digging of the Grand Canal of Sui and Tang Dynasties and Prosperity of Kaifeng City}

\subsection{Geographical Environment and the Historical and Political Evolution of Kaifeng}

Kaifeng is situated in the middle of the North China Plain, the south part of the big alluvial fan in the lower reaches of the Yellow River, where the Yellow River is to the north, the Yangtze and Huai Rivers are to the south, Shandong is to the east, and Zhengzhou 
and Luoyang Cities are to the west. The geographical coordinates of the terrain at which Kaifeng is situated are east longitude $113^{\circ} 52^{\prime} \sim 115^{\circ} 02^{\prime}$ and northern latitude $34^{\circ} 12^{\prime} \sim 35^{\circ} 01^{\prime}$, where the climate is a typical temperate continental climate: it is cold in winter, warm in spring, hot in summer, and cool in autumn, with four distinctive seasons. In Kaifeng, there are loose soil, several lakes, criss-cross rivers, and abundant underwater resources that are suitable for crop growth. The terrain in Kaifeng is flat, where the average altitude is 73 74 m. With this favorable natural geographical environment, Kaifeng was one of the earliest regions to be occupied by humans [11]. Early in the Neolithic age, our ancestors lived, grew, and bred there. In Kaifeng, there are the Duantougang Neolithic Early-Stage Peiligang Ancient Cultural (Weishi County), Tongliu Longshan Ancient Cultural, Zhulin Yangshao Ancient Cultural (Qixian County), and Lutaigang Shang Dynasty Cultural Relics. In the spring and autumn periods, Zheng Zhuanggong (the third monarch of Zheng's state in the Zhou Dynasty) (743 701 BC) expanded the territory in the central plain, built the city there and named it "Qifeng" [12], and built the earliest city wall and moat of Kaifeng. During the Warring States Period, in order to avoid the spearhead of the Qin State, Wei Huiwang (the third monarch of the state of Wei) (364 BC) relocated the capital here, and it was named "Daliang" [13]. In the Han Dynasty, the city name "Qifeng" was changed to "Kaifeng" in the first year of the reign of Emperor Jing (156 BC) (the sixth emperor of the Western Han Dynasty) for the sake of avoiding the forbidden word (as a taboo) contained in the name of the Emperor Jing Liu Qi. The name of Kaifeng is still in use today.

There were widely distributed lakes near the ancient city of Kaifeng, where there were criss-cross waterways, which were very favorable for the city's emergence, formation, and development. In its long history, Kaifeng's rise and fall were closely related to the development of the canal. In the Warring States Period, Wei Huiwang relocated the capital there and dug the Honggou Ditch to develop the economy, which made the city of Daliang prosperous. However, the good times did not last long; the Qin State unified six states and submerged the city with water; therefore, the city was destroyed. After the Tang Dynasty had ended, the Later Liang Dynasty, the Later Jin Dynasty, the Later Han Dynasty, the Later Zhou Dynasty, the Northern Song, and the Jin Dynasties founded Kaifeng's capital. Kaifeng is also called the "Capital of Seven Dynasties" [14]. The city of Kaifeng boomed in the spring and autumn Warring States Period, developed in the Sui and Tang dynasties, prospered in the Northern Song Dynasty, and failed after the Jin and Yuan Dynasties. Such a process was closely related to the Sui-Tang Grand Canal construction and the Beijing-Hangzhou Grand Canal.

\subsection{Shift of Economic and Political Center and Improvement of Kaifeng's Status}

Ancient China's economic focus tended to shift from west to east and from north to south in the long period of the feudal society. Due to the advantageous geographical environment, with its warm and humid climate, the Yellow River basin became the Chinese nation's earliest birthplace. The Guanzhong area in the middle and lower reaches of the Yellow River became the wealthiest region with the most developed agricultural economy in ancient China. Since the Qin and Han Dynasties, most of the regional economies in ancient China, except Hunan, Hubei, Chengdu Plain, and a few other regions, did not have a development process and were deprived. However, the increasing population, especially in the Yellow River basin, produced more and more demands on living and production materials, which was accompanied by the severe destruction of the ecological environment.

On the one hand, the dense forests, verdant grasslands, and a wide range of vegetation were destroyed, causing severe water and soil loss and frequent disasters. It resulted in the flooding of rivers in rainy seasons and droughts in the non-rainy seasons. Moreover, for a long time, the reclamation activity caused the elimination of grass and tree rootstocks and intensified the increasingly severe land impoverishment $[15,16]$. On the other hand, several lakes disappeared as the local water systems were destroyed. As the water resources were exhausted, the local hydraulic engineering and irrigation operations declined. 
The local agricultural drought resistance dropped, and the land's capacity for bearing population was greatly reduced. In the Qin and Han Dynasties, Zhengguo Canal irrigated more than 40,000 hectares of land, and Baigong Canal irrigated more than 400 or 500 hectares. These two canals were the most crucial water conservancy facilities in the Guanzhong area (Shaanxi Plain's central area). However, by the first year of the reign of the Emperor Taizong of the Song Dynasty (995 BC) (the second emperor of the Song Dynasty), the two canals could only irrigate 2000 hectares or less of land [17]. The scarce water resources severely restrained agricultural development. Whilst the productivity kept reducing in northwestern China, the continuous development in the south caused China's economic focus to shift to the southeast region since the Wei and Jin Dynasties. At the end of the Western Han Dynasty, central China was severely destroyed by the peasant uprising. To avoid the chaos caused by wars, a large number of people in Central China started to migrate to the Yangtze River basin. They brought advanced production tools and technologies to the region in the south of the Yangtze River. The fertile and rich regions in the south of the Yangtze River's lower reaches were thereby developed. By the Tang Dynasty, the cereals produced and harvested in the Guanzhong area could not meet the demands of the capital Chang'an; therefore, there was a frequent need to transport cereals from southeastern China to fill the supply gap [18]. By that time, the Yangtze River basin in the south had become the economic focus of China.

While the economic focus was shifted from northwest China to southeastern China, China's political center was also shifted from the west to the east. As the heart of the feudal empire, the geographical position of capital is important for the development of the city itself and the fate of the whole nation (state). When deciding the capital of a state, there is a need to comprehensively consider and weigh all involved parties' relationships, where the most important ones are military matters, politics, and the economy [19]. At the beginning of the Sui Dynasty, the domestic situation welcomed the fundamental change. The whole nation realized the unification. In order to consolidate the political unification, developing the economy and enhancing the control on the region in the south of the Yangtze River were required. This region was the main source of the materials supplied to the Guanzhong area. Emperor Wen of the Sui Dynasty was ordered to dig the Guangtong Canal in $584 \mathrm{AD}$ to transport various materials by water. Then transportation of cereals and other commodities from the region in the south of the Yangtze River by water became possible. In $587 \mathrm{AD}$, Emperor Wen of the Sui Dynasty ordered Liang Jun to consolidate the weir built in the Han Dynasty at Biankou to connect the Yellow and Bianhe Rivers. Later, Emperor Yang of the Sui Dynasty was ordered to dig the Tongji Canal (known as the Guangji Canal, otherwise known as the Bianhe River in the Tang Dynasty), thereby making the wish come true [20]. Since then, the Grand Canal, which was centered around Luoyang, passed through the Yongji Canal in the north till Zhuojun (known as Beijing today), and arrived at Hangzhou in the south, was dredged. Because Luoyang was located at the intersection of the South and North Canals, and the junction of the vast economic areas of Henan, Shandong, and the region in the south of the Yangtze River, Luoyang started flourishing. In view of the important strategic location, Emperor Yang of the Sui Dynasty established the capital there, meaning that China's political center shifted out of the Guanzhong area (Figure 3). 


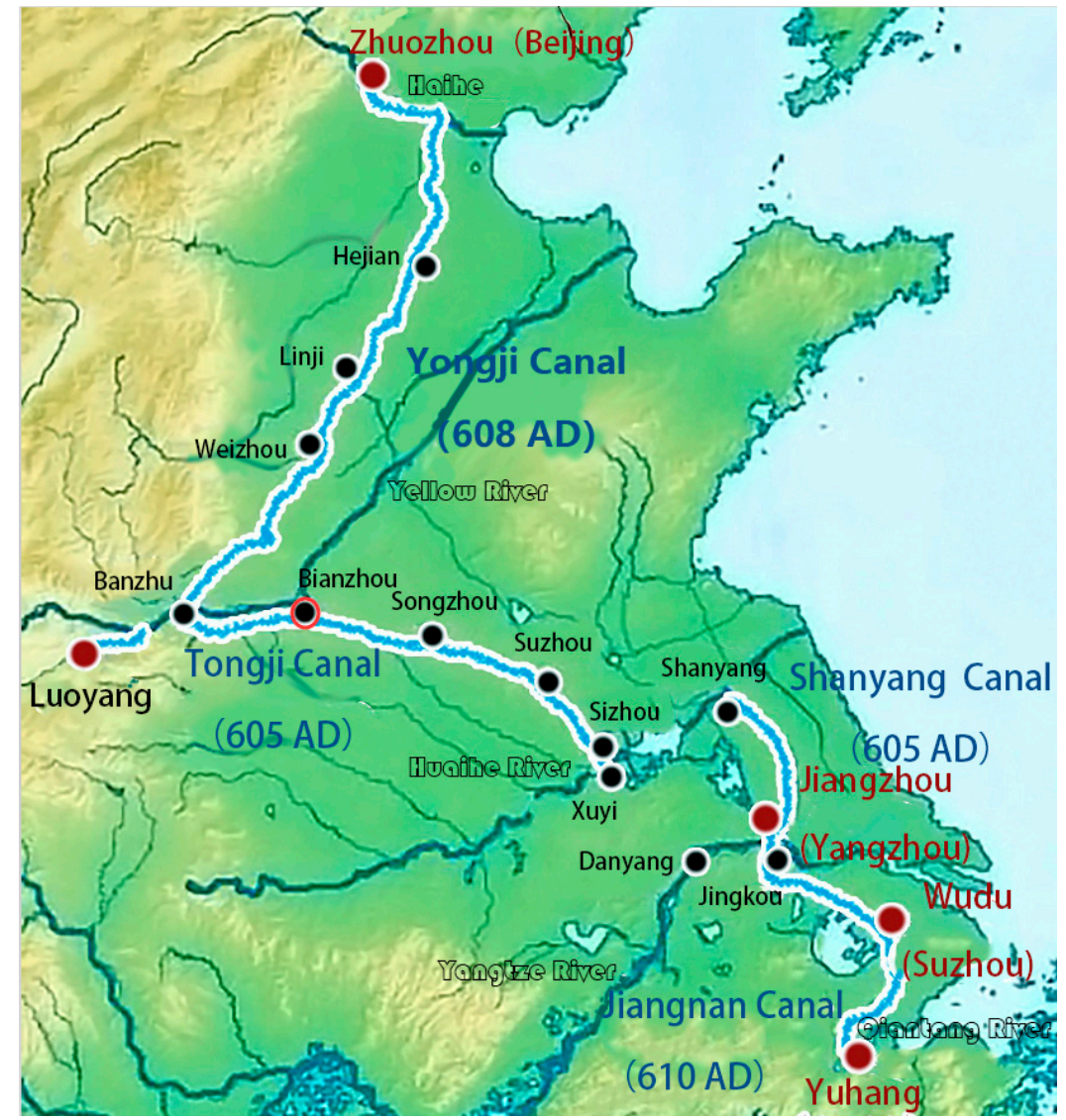

Figure 3. The Grand Canal of the Sui Dynasty went through five river systems in China. Bianzhou (Kaifeng) was located in the main center of the Grand Canal. (Source: https://www.sohu.com/a/23 7075031_580908, accessed on 2 July 2021).

The construction of the Grand Canal rapidly improved the urban status of Kaifeng. In the Sui and Tang Dynasties, China's economic focus was on the region in the south of the Yangtze River. However, the national political and military centers were still in the north The region in the south of the Yangtze River was the primary supply source of finance and tax revenues to the north. The Grand Canal of the Sui Dynasty was only constructed for military purposes. At the time, the Grand Canal was a military shipping lane and the political and military center's transportation artery in the north and the economic center in the south (the south of the Yangtze River). Li Jingfang, a person in the Tang Dynasty, described the dependency relationship between the politics in the north and the economy in the south as follows: the north acquired the wealth of 43 states in the southeast, all were from the Grand Canal [21]. After the Middle Tang Dynasty ended, the Grand Canal became the Tang Dynasty's lifeline as the dependency relationship between the Yellow River and Yangtze-Huaihe River basins was increasingly deepened. The Grand Canal, depending on whether it was blocked or unblocked, directly affected the rise and fall of the Tang Dynasty regime and the rise, fall, and alternation of many cities along the canal in Chang'an Luoyang and Kaifeng. Therefore, canal transportation had more critical significance in the political, economic, and military senses.

In the Tang Dynasty, Bianzhou (Kaifeng today) stretched across the canal and was the communication hub of the south-north transportation. As the Grand Canal became the bond between the regional economy in the south and north, Bianzhou's status was increasingly improved and gradually became the transshipment and distribution center of materials between the south and north. Bianzhou then further developed into a metropolitan city with developed industry, business, and a large population. The poem titled Things on Roads in Bianzhou, written by Wang Jian, delineated a flourishing and busy grass 
market at the Bianshui Ferry near Bianzhou: Passengers and merchants speaking different languages and came from different areas came over here for transactions through the 1000-mile canal with the green locust trees on both banks. What was sold on the grass market were various commodities that were transported using the canals, pass, ferry roads, and bridges, where merchants were charged levying taxes for their use [22]. This symbolized the prosperity of the busy Bianhe River. As such, it can be seen that at that time, Bianzhou benefited not only from canal transportation but also from the Yangze River and Huaihe River. The shift in economic focus and the formation of vast economic areas provided the economic precondition for Kaifeng's rise.

After the Lushan Rebellion in the Tang Dynasty was over, Kaifeng was the capital of six dynasties in succession. The Lushan Rebellion directly resulted in the destruction of imperial palaces in Chang'an and Luoyang by fire, and the economies in the regions surrounding both of them were severely destroyed [23]. Due to the Grand Canal construction, Bianzhou became the Tang Dynasty's central government's strategic area for controlling canal transportation and maintaining their governance [24]. At the time, Bianzhou's particular political, economic, and military statuses were incomparable to that of Chang'an and Luoyang. Therefore, by adopting Bianzhou as the capital, Zhu Wen, Shi Jingtang, and Zhu Quanzhong founded three regional separatist powers by the end of the Tang Dynasty. Following the Later Zhou Dynasty and the Northern Song dynasty, Bianzhou was also adopted as the capital. Since then, Bianzhou had entered into a new historical development stage and developed into a nationwide political center by replacing Chang'an and Luoyang.

According to the historical geographer Shi Nianhai, the critical reason that Kaifeng became an important city in several dynasties was the developed canal system, namely, the "nationwide canal transportation center." As he said: "Why did Kaifeng become the capital of the Northern Song Dynasty? The reason is that Kaifeng is located in the place where extends in all directions" [25]. In the agricultural era, an essential law of China's urban development was the city's development priority being the political center. The development scale and speed of a city are directly proportional to its high or low political or administrative status. The higher the city's political-administrative status, the more extensive the city's development scale, and the quicker the city's development speed. In contrast, the lower the city's political-administrative status, the smaller the city's development scale, and the slower the development speed of the city [26]. The political center can easily acquire funds, a labor force, and technology through the government's administrative power. Therefore the "administration center" may develop quicker than other cities of the same size [27]. According to American scholar Robert Hartwell, the capital Kaifeng's prosperous economy was profoundly affected by administrative factors [28]. In the Later Zhou Dynasty, Zhou Shizong (the second emperor of the Later Zhou Dynasty) dredged the canal net around Kaifeng to allow Kaifeng to prosper, where the large-scale urban construction laid the basis for Dongjing's (the other name for Kaifeng in the Northern Song Dynasty) ability to achieve great prosperity. After choosing Kaifeng as the capital in the Northern Song Dynasty, all resources started to gather together in Kaifeng, which vigorously pushed the development of Kaifeng's water transportation. After the Later Zhou Dynasty ended, the Northern Song dredged the Bianhe, Wuzhang, and Caishui Rivers, and constructed the Jinshui River to establish the "four canal systems" that running through the capital (Figure 4). In turn, the water transportation pushed Kaifeng's urban development, making Kaifeng become the genuine political, economic, and cultural center for the country by that time.

In short, why did the Song Dynasty choose Kaifeng as the capital? Why did Kaifeng rise rapidly? Why did Kaifeng become a worldwide metropolitan city? All of these factors were decided by the political, economic, and cultural development by that time. The gradual shift of national political and economic focus provided the opportunity for a prospering Kaifeng, and the development of the canal net directly pushed Kaifeng's prosperity. 


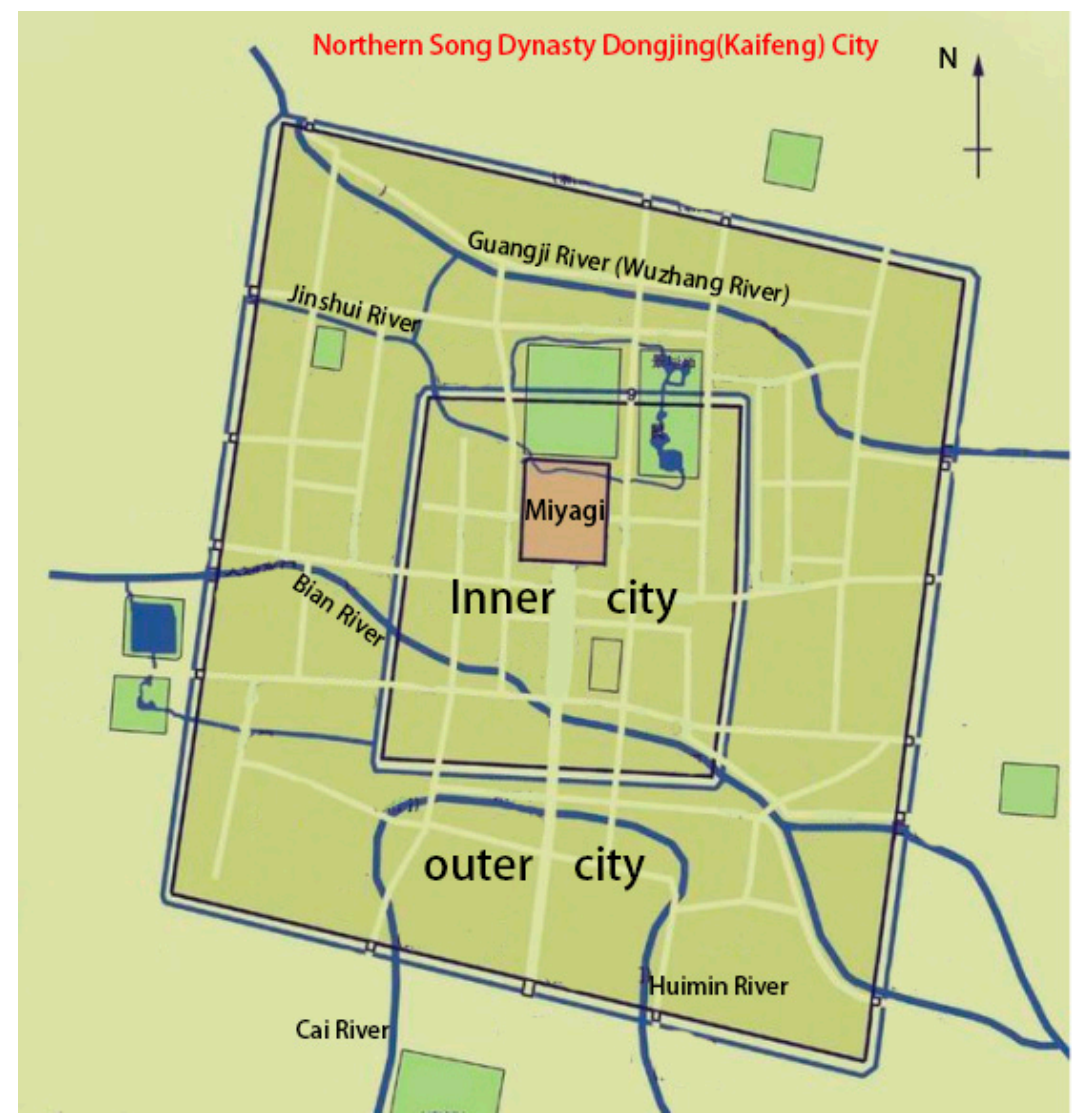

Figure 4. The vast size of Kaifeng in the Northern Song Dynasty and the four canals that passed through the city.

\subsection{Bilateral Interaction of the Grand Canal and the Urban Development of Kaifeng}

\subsubsection{The Development of the Grand Canal Directly Improved the Prosperity of Kaifeng}

The developed canal network was vital for Kaifeng to prosper in the 6th 12th centuries. Since the Sui and Tang Dynasties and the Five Dynasties, Bianzhou gradually became the transportation junction, and it was also called a "metropolis rejoined by water and land" [29]. By the Kaiyuan period, Bianzhou started to prosper. In the Later Zhou Dynasty, the Caihe, Wuzhang, and Bianshui Rivers were connected to form a developed water transportation network. Kaifeng was the center of nationwide water transportation, where there was a prominently important transportation status [30]. After the Northern Song unified the whole state, Kaifeng was chosen as the capital; it was called "Dongiing (Eastern Capital)." The number of Kaifeng citizens was increased by ten times than before, and there were one hundred thousand soldiers; the vast population was increased by relying on the canal. The importance of the canal was obvious. Zhao Kuangyin, Emperor Taizu of the Song Dynasty, called the canal the sacred belt. Emperor Taizu said: "We have other scared belts, one is Bianhe River, one is Huimin River, and another is Wuzhang River" [31]. In order to prevent a military disaster, the governor established "locality separatist power" in the Five Dynasties at the end of the Tang Dynasty. From the troops' station in Kaifeng, the pattern of strengthening the central forces and weakening the local ones was formed [32].

The Song Dynasty needed to have enough cereals and materials to supply the troops in the capital. Given that the context that the national tax revenue relied on the southeastern regions, the unblocked canal transportation must be maintained. Therefore, besides dredging the original Bianhe (Tongji Canal) and Wuzhang Rivers, the Northern Song Dynasty government constructed the Jinshui and Huimin Rivers (Caihe River). Along with the Yellow River, these four canals were distributed in a radial pattern near the capital 
Kaifeng. The Bianhe River entered the outer city via two branches from the Hongqiao in the southeast, and both branches rejoined near Shangto Bridge and then entered the inner city. Finally, the river left the city from the northwest. Wuzhang River entered the outer city from the northeast and then left the city from the north. The Jinshui River went directly to the imperial palace. The Caihe River (Huimin River) surrounded the Nandong Gate of the outer city and the Zhuque Gate of the inner city via one circle with two branches in the south and the north, and then entered and left the city by passing through the Hulong River in the south. By connecting with the Hulong River, these four canals were interconnected and thereby formed a water transportation net like a cobweb, which extended in all directions. Kaifeng became the nationwide transportation junction and then became the capital, extending to all directions and controlling the whole state [33] (Figure 5). Every year, there were 3000 7000 ships frequently running on the Grand Canal, which was the highest record in canal transportation history. Till the end of the Qing Dynasty, it was far lower than the record. Therefore, it was a brilliant chapter in the history of inland water transportation in ancient times. As the urban scale kept increasing, Kaifeng's industry and commerce were increasingly flourishing, which was mainly manifested by the developed canal transportation, the rapid expansion of the urban scale, and the prosperous industry and commerce.

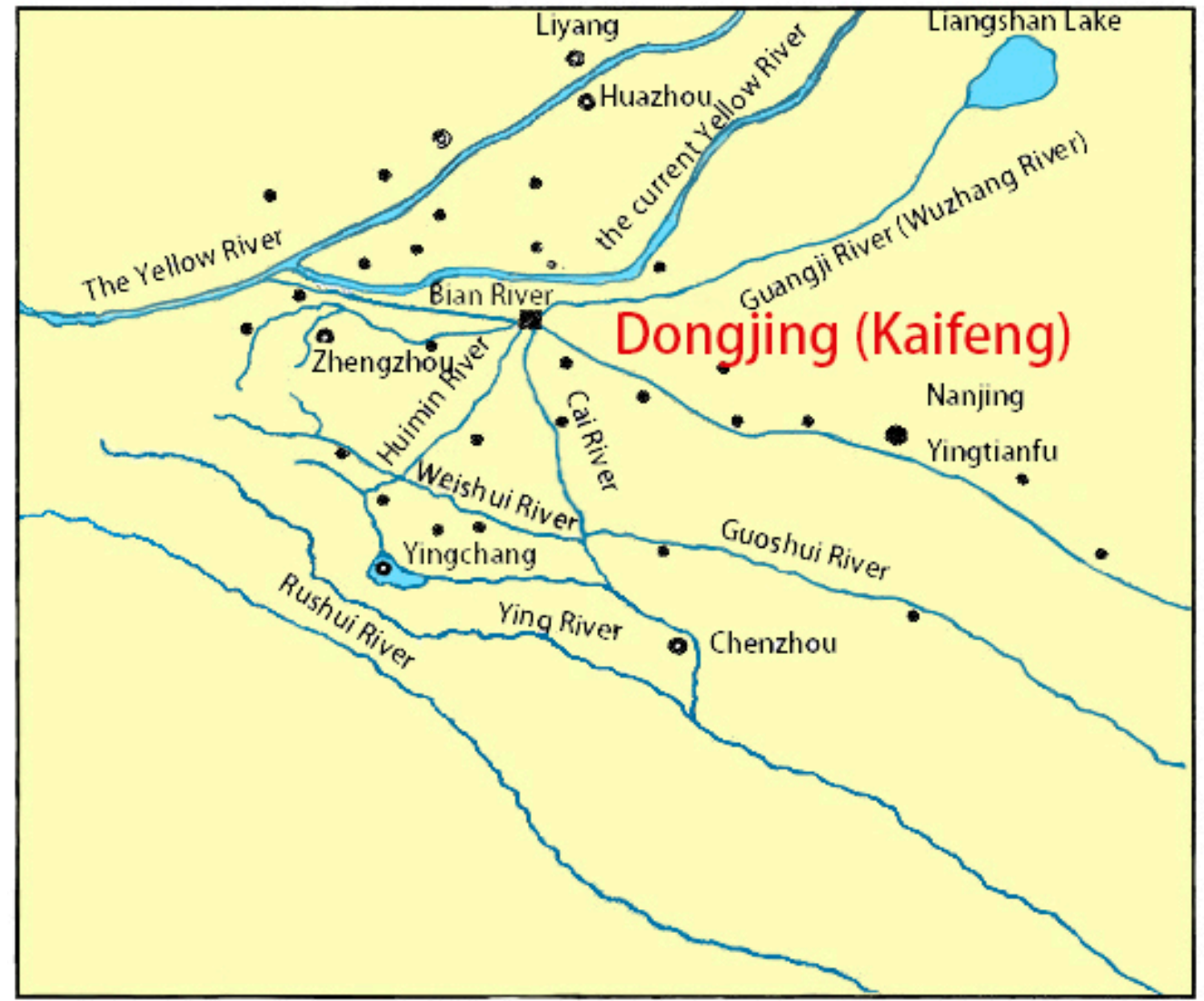

Figure 5. Radial canal net surrounding Kaifeng, the capital of the Northern Song Dynasty. (Map developed by the authors—https://m.sohu.com/a/230859384_556504, accessed on 2 July 2021).

Development of canal transportation: The prime function of the canals was to transport governmental cereals. In the Northern Song Dynasty, the amount of finances and taxes transported to the capital and the northern regions by the canal was far more than that of the Sui and Tang Dynasties every year. By that time, the busy canal transportation could be certified by the Ode to Biandu (Kaifeng), which was written by Zhou Bangyan. For only the cereals, 3 7 million dans (a unit of dry measure for grain) were transported to the capital via the canal bypassing through Liangzhe, Huainan, Jiangdong, Jiangxi, Hubei, and Hunan 
(collectively known as the "Southeastern Six Ways"), and 8 million dans were transported during the period between the regime of the Emperor Zhenzong of the Song Dynasty and the Emperor Renzong of the Song Dynasty [20]. The convenient water transportation and the collection of various materials from the south and the north attracted various merchants to gather together in the capital, which laid the material basis for the prosperity of Kaifeng and the maintenance of the regime of the Northern Song Dynasty. For example, Zhang Fangping, the Northern Song Dynasty economist, said: "Looking at the current situations, the state is protected by the troops, foods raise the soldiers, the foods are transported by canal transportation, rivers and canals achieve the canal transportation" [34]. The developed unobstructed canal network expedited Kaifeng's logistics, human flow, and information flow, which enhanced Kaifeng's agglomeration effect and pushed Kaifeng to develop into an international city very quickly. Therefore, we can say that the canal was the lifeline of Kaifeng and a critical factor for the rise of Kaifeng into a flourishing city.

Expansion of the urban size: The Northern Song Dynasty was the period of great prosperity achieved by Kaifeng. By that time, there was an unprecedented large urban size and a very flourishing economy in Kaifeng. There was a population of more than 1 million in Kaifeng, and was a globally famous city. The city of Kaifeng was composed of the outer city, inner city, and imperial city. The outer city's perimeter was $50 \mathrm{li}+165$ strides (more than $26 \mathrm{~km}$ ), approximately equal to the earthen city relics around Kaifeng today. The inner city was located in the central part of the outer city. Its perimeter was $20 \mathrm{li}+50$ strides (more than $10 \mathrm{~km}$ ), approximately equal to the size of Kaifeng today. The imperial city was located in the northward central part of the inner city; its perimeter was $9 \mathrm{li}+18$ strides (more than $4.7 \mathrm{~km}$ ) [35-37]. The neat urban layout, imposing and magnificent palaces and pavilions, and prosperous industrial engineering and commerce were well known worldwide.

Prosperous industry and commerce: In the Dongjing of the Northern Song Dynasty, commerce was highly prosperous, and the neighborhood system had imposed restrictions on commercial development. The city of Kaifeng had started to turn into a "street and alley system" from a neighborhood system [38]. In the Tang Dynasty, where the markets were established along streets, there were stores and shops in great numbers. In the period of great prosperity, the population was more than 1.50 million in Kaifeng in the Northern Song Dynasty [39]. Merchant princes and tycoons from various areas were gathered there, and rare department goods from across the nation were sold here. By that time, Kaifeng was the place that people from all directions were anxious to go. All countries were eager to come for communication [40]; it was stated that "the splendor of Dongjing (Kaifeng) was unparalleled in the world." In the time in the reign of the Emperor Zhenzong of the Northern Song Dynasty, many households were owning a million assets, and the households owning one hundred thousand assets could be found everywhere in the capital Kaifeng [41]. Stores, shops, and colored flags were even covering all the sky. Each transaction has a value of tens of millions [39]. The GNP (gross national product) was more than ten times that of the Han Dynasty and the Tang Dynasty [41]. Shiba Yoshinobu, a Japanese historian, argued that in the Song Dynasty, the long-term southward migration of the northern population, and the rapid development of the southern economy since the Three Kingdoms Period prompted the nationwide economy focus to shift southward. The finances and taxes in the south showed a tendency of contending against the politics and military consumption in the north. Such a regional labor division resulted in the flow of plenty of materials, improved the functionality of transportation and commerce, and resulted in the rise of domestic urban commerce and the concentration of commerce. If there was no transportation net centered by the canal, whether it was the inter-local trade or the long-distance trade, none of them could be completed [42]. Overall, the influence of the canal on the commercial prosperity of Kaifeng was obvious.

Zhou Bangyan, the ci writer of the Northern Song Dynasty, delineated Kaifeng's busy water transportation scenes in the famous ci called Ode to Bianjing, which described unprecedented grand scenes. Zhang Zeduan, the painter of the Northern Song Dynasty, 
vividly portrayed the canal navigation's grand occasions in Kaifeng in the famous painting Riverside Scene at Qingming Festival, which reflects the busy and flourishing scenes on both banks of the Bianhe River inside Kaifeng (Figure 6). According to the Riverside Scene at the Qingming Festival, the developed water transportation network system was the key condition of Kaifeng's prosperity. The canal net created extremely beneficial preconditions for the economic prosperity and cultural exchange in Kaifeng. Miyazaki Ichisada especially stressed the significance of transportation in historical research. He spoke highly of the role of the canal in the historical development of the Song Dynasty. He presented an idea of "the time centered by canal" in the publication titled Modern Times of Japan [43]. The development of the canal opened unprecedented scenes of the commercial business of the Song Dynasty. Based on the "Theory of Central Places" by Christaller, a German geographer, an American scholar called G. William Skinner studied the urban history of China and the regional economy history that developed around the central cities. He divided China into nine regions and thought that the regional economy had different development periods. The development peak of the North China Cycle, centered on Kaifeng, was in the Northern Song Dynasty. Where the formation of canal net and road net facilitated the effective collection of revenues and tributes, this stimulated the regional specialization of the extractive and manufacturing industries, which promoted the expansion of the trade area of Kaifeng and other cities, and laid the basis for the total volume of trade that allowed for achieving large-scale growth. Moreover, he thought that the medieval urban revolution that happened in China started in the first century AD, but achieved its peak in the Southern Song Dynasty [44].

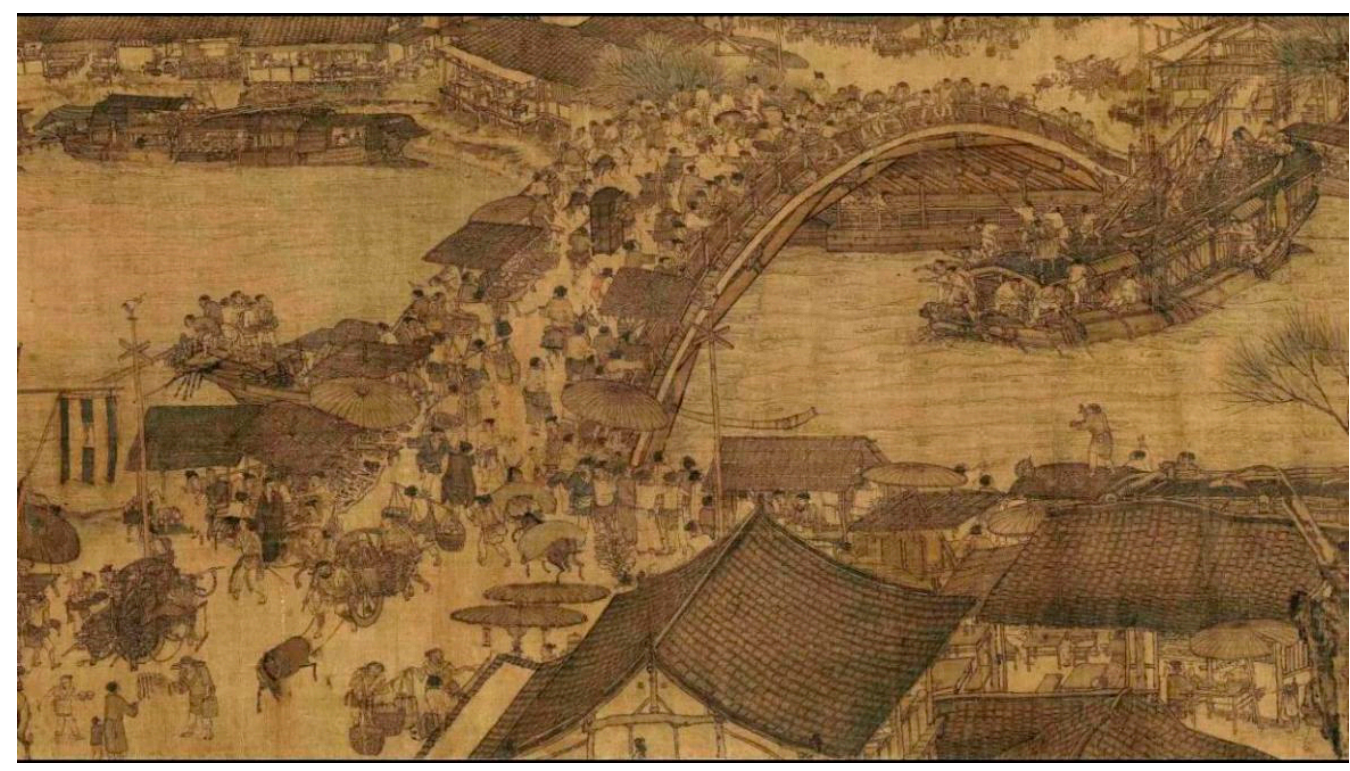

Figure 6. Upriver area during the Qingming Festival.

\subsubsection{Prosperity of Kaifeng Also Promoted Canal Development}

The prosperous economy and booming culture of Kaifeng also promoted the development of the canal. To guarantee an unblocked water transportation network, the government of the Northern Song Dynasty established a complete set of strict and rigorous protection systems. Moreover, the full-time officers were assigned to take control of the canals [33]. During the reign of the Emperor Renzong of the Northern Song Dynasty, the riverbeds were dredged every year; therefore, all canals were relatively unblocked for navigation in the early time of the Northern Song Dynasty [33]. In 1015 (8th year in Dazhongxiangfu, the third reign of the Emperor Zhenzong of the Northern Song Dynasty), the practice of dredging the Bianhe River annually was suspended and changed into the practice of dredging riverbeds every three or five years. In 1051 (3rd year in Huangyou, the reign title of the Emperor Renzong of the Northern Song Dynasty), the Emperor Ren- 
zong of the Northern Song Dynasty established the Rivers and Canals Department to be in charge of the dredging business. In 1058 (3rd year in Jiayou, the ninth and last reign of the Emperor Renzong of the Northern Song Dynasty), the Rivers and Canals Department was abolished. However, the water supervisor was assigned to exercise its powers [45].

The use of wood banks was another effective measure of the government of the Northern Song Dynasty for controlling the water of the Bianhe River. Due to the sediment accumulation and slow water flow, the canal transportation was deeply affected; therefore, the government adopted the method to control water, namely, tree branches were bundled, then these bundles were connected and placed on both sides of the Bianhe River. Finally, they were fixed with the piles. Such a method achieved a better water control effect [46].

Furthermore, in order to consolidate the embankment, the government of the Northern Song Dynasty encouraged the planting of trees on the banks of the Bianhe River in the early time of its reign. Willows can tolerate water well and grow fast. The locust tree and elm have a stiff quality; the materials for dredging riverbeds and maintaining the Bianhe River could be acquired locally. These trees were planted in large numbers to save costs. Emperor Taizu of the Song Dynasty ordered the planting of trees on both banks of the Bianhe River; the first order was given in 962 (3rd year in Jianlong, the reign title of the Emperor Taizu of the Song Dynasty): all officers of prefectures and counties along the river must mobilize the public to plant elms and willows on both banks of the canal so as to consolidate the embankment [47].

Additionally, the Northern Song Dynasty government enacted a complete set of appraisal methods to link the tree plantation with the canal governance results of officers. As was shown using archaeology, plenty of willows (Salix matsudana), elms (Ulmus pumima), aspens (Populus spp.), and peach trees (Amygdalus persica) were planted on both banks of the Bianhe River [48]. Many poems intoning willows showed that many willows were planted on both banks of the Bianhe River. Moreover, many locust trees (Sophora japonica) were planted too. Wang Jian, the poet, delineated rows of green and lush locust trees on both banks of the Bianhe River. These lush trees constituted the green shield to protect the Bianhe River.

\section{Destruction and Oblivion of Canal Systems in the Later Northern Song Dynasty and Fall of Kaifeng}

3.1. Political Corruption in the Later Northern Song Dynasty Caused the Canals in Kaifeng to Be under Bad Repair for a Long Time

In the Later Northern Song Dynasty, political corruption and a slack control system for canal transportation and rivers caused all canals to fall into disrepair and sediments built up. Since the more severe sedimentation and the developed rivers were submerged by the frequent overflow of the Yellow River, the flood disasters frequently happened in every rainy season [49]. The bed accretion caused the Bianhe River to become an overground river. Thus the water transportation environment in Kaifeng became more and more deteriorated, where the functions of the canals were lost [41]. The change in the water transportation environment in which Kaifeng relied on for achieving prosperity caused a severe impact on the external economy and trade communication. As such, the city of Kaifeng has declined since then. Since the canals could not effectively link China's political, military, and economic centers, the Northern Song Dynasty finally ended.

\subsection{Shift of Political Center Abolished the Canal System of Kaifeng}

In 1127, the troops of the Jin Dynasty marched down south to attack and conquer Dongjing, the capital of the Northern Song Dynasty, and captured Emperor Huizong and Qinzong, which resulted in the end of the Northern Song Dynasty; this is known as the "Event of Jingkang." Zhao Gou abandoned the central plains and finally chose Lin'an (Hangzhou City nowadays) as the capital. As a result, the national political center shifted away from Kaifeng. In 1141, the Southern Song Dynasty and the Jin Dynasty set the Huaihe River as the boundary. Both dynasties were set against each other for a long time; the unified Song Empire was separated. Till the later period of the 13th 
century and before the Yuan Dynasty was founded, the southern and northern regimes were strongly opposed to each other, with tensions sometimes breaking out in warfare. The Yuan, the Ming, and the Qing Dynasties chose Beijing as the capital; therefore, the canal transportation was done using the Beijing-Hangzhou Grand Canal that was dug during the Yuan Dynasty. In 1283 1293, the Yuan Dynasty dug the Beijing-Hangzhou Grand Canal, which was based on the Grand Canal of the Sui Dynasty. It started from the Great Capital of the Yuan Dynasty in the north; passed through Hebei, Shandong, Jiangsu, and Zhejiang; and ended in Hangzhou in the south. The canal transportation did not pass through the Central Plains anymore. The shift of the political center and the change of the canal line made the Bianhe River lose the value of bridging the south and north; since then, the Bianhe River was out of use for a long time. There were too much deposits and its water flow was cut off; therefore, the economy of the south and north was blocked. The city of Kaifeng, after prospering for more than a century, had lost its prosperity (Figure 7).

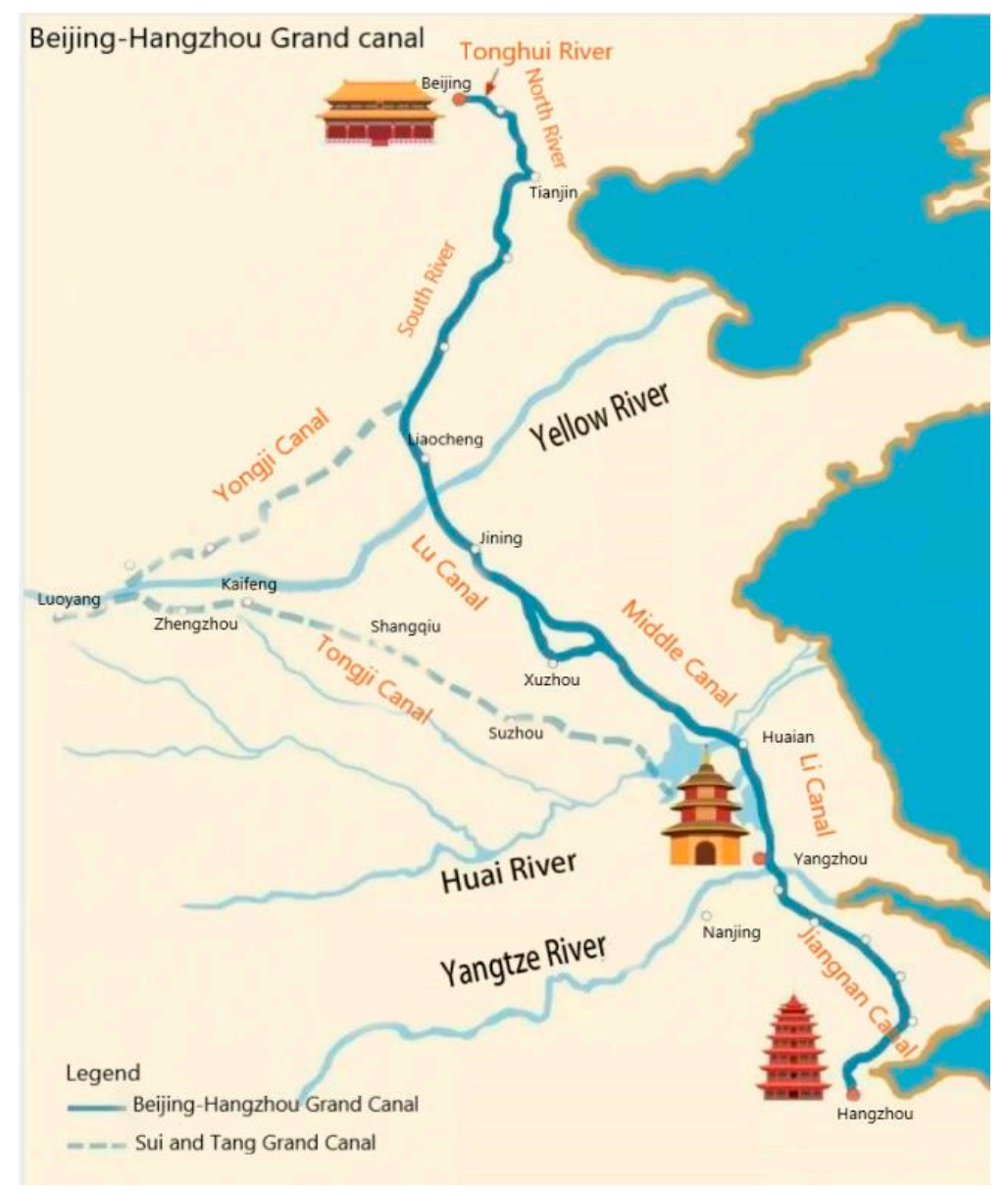

Figure 7. The Beijing-Hangzhou Grand Canal replaced the Sui-Tang Grand Canal in the Yuan Dynasty; as a result, Kaifeng was finally marginalized.

\subsection{Diversion of the Yellow River Caused Physical Damage to the Canal System in Kaifeng}

At the end of the Northern Song Dynasty, the main stream of the Yellow River swayed southeastward and frequently entered the Huihe River from the waterways of the Bianhe, Sihui, Woshui, and Yinghe Rivers. It caused most rivers and lakes between the Yellow River and the Huaihe River to be submerged by the inundation from the levee breaches of the Yellow River. More than 40 years later, after the Southern Song Dynasty was established, the watercourse of the former Bianhe River turned into cornfields somewhere, with villages scattered there. Till 1165 1173 (namely, the period of Qiandao, the second reign title of the Emperor Xiaozong of the Southern Song Dynasty), the Bianhe River was almost flush 
with both banks and army horses walked on it. Other canals, such as the Wuzhang and Huimin Rivers, were almost abolished at the same time.

From this, it can be seen that after the Northern Song Dynasty was ended and as the water system of Bianhe River was destroyed, the city of Kaifeng gradually suffered from the deteriorated surrounding ecological environment. Then it gradually became an unnavigable city; as such, the economic and trade contact between Kaifeng and other provinces was restricted. Since the economic basis of Kaifeng was weakened, the sustainable development of Kaifeng was restrained tremendously. Due to the busy transportation and trading conditions that were relied on were destroyed, the economic and trade center in the entire Yangtze River-Huaihe River region was gradually shifted out of Kaifeng. The Southern Song Dynasty was located in the south of the Yangtze River; therefore, Kaifeng lost the status of being the political center, and the city status of Kaifeng went "from bad to worse." Later, the Yuan, Ming, and Qing Dynasties chose Beijing as the capital; therefore, the canal transportation was undertaken using the Beijing-Hangzhou Grand Canal that was dug during the Yuan Dynasty. The shift of the political center and the change of the canal system caused Kaifeng to decline. Till the middle term of the Qing Dynasty, the water systems in Kaifeng were frequently destroyed by the flooding of the Yellow River; as such, the advantages in the water conservancy and transportation in Kaifeng were utterly lost. By the end of the Qing Dynasty, Kaifeng became an ordinary city in the central plains.

\section{Conclusions}

A city may form and develop under the influence of various factors, such as ecological environment factors, transportation factors, technical factors, and political factors. As a city, Kaifeng has a history of more than 2000 years, and seven dynasties founded their capital there. The Grand Canal played a decisive role in helping to turn Kaifeng into a flourishing city from an unknown city. As a folk song popular to the folks in Kaifeng goes: "Kaifeng is flourishing if the Bianhe River is unblocked for navigation, but is declined if the Bianhe River is abolished." It reflects the close relationship between the rise of Kaifeng and the canals. If there was no Grand Canal, there would have been no 168-year prosperity of Dongjing, the capital of the Northern Song Dynasty, or the great painting of the Riverside Scene at the Qingming Festival. By investigating the relations between the Grand Canal and the rise and fall of Kaifeng, we can know that the history of the rise and fall of Kaifeng, to some extent, is the history of the rise and fall of the Grand Canal. In the Warring States Period, the unblocked Honggou water systems caused the city of Daliang (Kaifeng today) to flourish. In the Sui Dynasty, Kaifeng was known as the Bian; it was only a very common county. The Emperor Yang of the Sui Dynasty dug the Grand Canal by taking advantage of the ancient Bianqu Canal, which passed through the county of Bianzhou and laid the status of "nationwide canal transportation center." In the Tang Dynasty, the political status in the north relied on the cereals transported from the canal systems after the economic focus was shifted to the south. Bianzhou took the opportunity and then developed into a famous commercial capital. Due to the problems of the Tang Dynasty military governors, multiple military governors in the north controlled the grains and taxes. They withheld the grains and taxes without paying them to the central government. Therefore, the Tang Dynasty government had to rely on the counties in the region in the south of the Yangtze River, where the Grand Canal became the lifeline of the Tang Dynasty. The political status of Bianzhou was becoming increasingly important. To consolidate the control on Bianzhou, the government of the Tang Dynasty expanded the city of Bianzhou; such special political protection and advantageous water transportation pushed the urban economy of Bianzhou to develop rapidly. In the Later Liang Dynasty (during the period of the Five Dynasties), in order to acquire the material support of the region in the south of the Yangtze River, Zhu Wen utilized the advantageous water transportation of Bianzhou and founded the capital in Kaifeng. In the Later Zhou Dynasty, the water transportation of Bianzhou became unobstructed as a series of dredging operations were conducted, which facilitated merchants to gather there. After the Northern Song Dynasty founded the capital in Dongjing (Kaifeng 
today), it was a milestone shift of ancient China's capital from west to east. In terms of military defense, the geographical position of Kaifeng was not so appropriate; however, Kaifeng was chosen as the capital of the Northern Song Dynasty due to its advantageous economic conditions. The convenient canal transportation in Dongjing (Kaifeng today) in the Northern Song Dynasty allowed industrial engineering and commerce to flourish and prosper and allowed the resident population to increase. Therefore, Dongjing (Kaifeng today) became a more thriving political, economic, and cultural center than other dynasties. After the Song Dynasty ended, three dynasties, namely, the Yuan, Ming, and Qing Dynasties, founded the capital in Beijing in succession; as such, the national political center was shifted out of the Yellow River basin. Moreover, due to the frequent water floods of the Yellow River, the concentrated man-made canals surrounding Kaifeng declined from their prime. Significantly, the construction of the Beijing-Hangzhou Grand Canal in the Yuan Dynasty made the canal transportation avoid passing through the Central Plains. The pivotal role of Kaifeng in the transportation of grains from south to north finally ended in 1411. Since then, the urban status of Kaifeng dropped dramatically, it was marginalized, and its past brilliance is no more.

In China, the canals and the canal-centered cities all rose and fell together. The canal created the necessary conditions for the rise of the city. The shift of the canal inevitably caused changes in the urban size and the rise or fall of the urban economy. In the urban development history of China, such examples are not unusual. Besides Kaifeng, the navigation of the canal between the Yangtze and Huaihe Rivers in the Han Dynasty stimulated the rise of Yangzhou. The canal's connection in the region in the south of the Yangtze River, the Qiantang River, and the Zhedong Canal pushed Hangzhou to develop into a big economic city from a coastal town. As the canal in the south of the Yangtze River was re-opened for navigation in the period of Yongle (the reign name of the third Emperor Chengzu of the Ming Dynasty), Hangzhou was replaced by Suzhou. As the capital of the Yuan, Ming, and Qing dynasties, Beijing has always been known as the "buoyant city." Millions of dans of grains and other materials were transported to Beijing via the Grand Canal every year. Jining and Linqing, in the territory of Shandong, developed rapidly after the Beijing-Hangzhou Grand Canal was constructed. In 1855, the waterway from Anshan to Linqing dried up due to the levee burst of the Yellow River. In 1874, the canal ships were replaced by seagoing vessels. In 1900, canal transportation was totally abolished; the traditional canal systems were disassembled. All canal-centered cities, such as Yangzhou, Jining, and Linqing, started to fall, but other canal-centered cities, such as Suzhou, Hangzhou, Wuxi, and Zhenjiang, created new development since the canal in the region in the south of the Yangtze River was still used.

While the canal promotes urban development, it can even profoundly influence the overall transformation of an era. Presently, there are plentiful achievements in the research on Kaifeng of the Northern Song Dynasty in the academic circles of Japan. Naito Konan pioneered proposing the "Theory on Changes in the Tang and Song Dynasties" by relying on the idea that the development of the Grand Canal allowed the commerce of the Song Dynasty to prosper, and a series of changes different from previous dynasties happened in the Northern Song Dynasty [50]. For instance, the development of canals resulted in the "transportation revolution," and thereby caused the "commercial revolution," and finally caused the development of the commerce of Donging (Kaifeng today) in the Northern Song Dynasty. It further caused the profound reform in urban development, the disassembly of the traditional neighborhood market, and the emergence of new streets and markets. Since then, the urban development of ancient China entered a new stage.

Moreover, the commercial development resulted in the agricultural, monetary, and credit revolutions [51]. The prosperous economy laid the material basis for the development of scientific technology. From this, it can be seen that the canal had a very profound influence on the society of the Song Dynasty. As was described by Mr. Qian Mu: "If discussing the changes of China's ancient and modern society, the most important one is the Song Dynasty." China before the Song Dynasty was Ancient China, China after the Song Dynasty 
has been contemporary China. In the Song Dynasty, the politics, economy, society, and life of China were changed greatly [52].

To sum up, along with the changes in the ecological environment and climate, China's economic center gradually shifted to the southeast, followed by the shift of the national political center from the west to the east. In this context, the operation of the Grand Canal ran through the entire economic regions of Henan, Hebei, and Jianghuai, thus significantly strengthening the economic exchanges in these regions. When the economic relationship between the regions is increasingly close, it gradually forms a broader economic region, which produces higher-level cities, thus forming a hierarchy system among cities. Located on the canal, Kaifeng was the key to waterway transportation and had an important strategic position. The capital of the Northern Song Dynasty was established there, and Kaifeng developed into the largest city in China and even in the world. After the Northern Song Dynasty, the canal was blocked, the traffic was abandoned, flooding was frequent, and Kaifeng appeared to decline. Since the Qing Dynasty, Kaifeng has lost its position as a transportation hub, and it also declined into a general town in the Central Plains. Through the above investigation and analysis, we can draw the following conclusions.

First of all, land and water transportation is the key factor of urban and regional development. A city is an open system. The smooth connection between the city and the outside is the basis for the survival and development of a city. A city is always carrying out an exchange circulation of materials and population, as well as the transformation and dissemination of information, with other cities and the surrounding hinterlands, where traffic plays a key role. Most of the cities in the world developed into primarily metropolitan areas because they are located on the traffic arteries; likewise, the shift of traffic arteries often leads to the decline of cities. In the Northern Song Dynasty, Kaifeng was located in the regional center of a canal economy, which allowed it to develop into a world-class metropolis with its geographical advantages of water transportation. However, in the Qing Dynasty, although Kaifeng was maintained as the capital of Henan Province, it inevitably declined due to the loss of transportation advantages. Kaifeng is a typical city of this kind in terms of the factors under discussion.

Especially in ancient China, the launching and blocking of the canal played such a key role in the development of a city and region, which was determined by the land and water traffic conditions at that time. The waterway was the most important mode of transportation in the past because of its advantages of low price, large transportation volume, and high speed. Before the rise of modern railway and ocean shipping, inland shipping through canals was the main form of transportation. In order to show the advantages of ancient water transportation, this paper makes a comparison with the prices of passenger and freight transportation in the Jiangnan region of China at the end of the 19th century (Tables 1 and 2). It is not difficult to see that water transportation had a large carrying capacity and longer journey distance, as well as the characteristics of the least labor cost and the lowest price.

From the data in the above two tables, we can calculate that for land transport, the average passenger transport was $400 \mathrm{wen} /$ person/100 li, and the average freight transport was $290 \mathrm{wen} / \mathrm{dan} / 100 \mathrm{li}$; for waterway transportation, passenger transport was only $150 \mathrm{wen} /$ person/100 li and freight transport was only 7 wen/dan/100 li. In comparison, the passenger transport cost via water was only $38 \%$ of that by road, and the freight transport cost via water was even less than $3 \%$ of that by land, which shows the advantages of water transport in ancient times. Because of these advantages, the development of water transport often became the key factor for the prosperity of cities in this region. 
Table 1. Price list of passenger transport in the Jiangnan region of China at the end of the 19th century.

\begin{tabular}{|c|c|c|}
\hline Transportation Type & Price & Note \\
\hline Small ship & $\begin{array}{l}120 \text { wen per person per day } \\
\text { or per } 100 \mathrm{li}\end{array}$ & \\
\hline Large ship & $\begin{array}{l}185 \text { wen per person per day } \\
\text { or per } 100 \mathrm{li}\end{array}$ & $\begin{array}{c}\text { No steamship competition plus } \\
\text { liquor charge }\end{array}$ \\
\hline Large ship & $\begin{array}{l}133 \text { wen per person per day } \\
\text { or per } 100 \mathrm{li}\end{array}$ & $\begin{array}{l}\text { With steamship competition plus } \\
\text { liquor charge }\end{array}$ \\
\hline Sedan chair & $\begin{array}{l}360 \text { wen per person per day } \\
\text { or per } 80 \mathrm{li}\end{array}$ & $\begin{array}{l}150 \text { wen as the labor's meals } \\
\text { compensation, total was } 630 \text { wen per } \\
\text { person per } 100 \mathrm{li}\end{array}$ \\
\hline Mule horse & $\begin{array}{l}350 \text { wen per person per day } \\
\text { or per } 75 \mathrm{li}\end{array}$ & Only available in a few locations \\
\hline Donkey & 200 wen per person per day & $\begin{array}{l}\text { Plus animal food fee and meals } \\
\text { compensation for donkey owners }\end{array}$ \\
\hline
\end{tabular}

Table 2. Price list of freight transport in the Jiangnan region of China at the end of the 19th century.

\begin{tabular}{|c|c|c|}
\hline Transportation Type & Price & Note \\
\hline Small ship & $\begin{array}{l}1000 \text { wen per } 100 \text { dan per } \\
\text { day or per } 100 \mathrm{li}\end{array}$ & $\begin{array}{l}\text { There was a discount for a longer } \\
\text { distance of approximately } 800 \text { wen }\end{array}$ \\
\hline Large ship & 5.1 wen per dan or per $100 \mathrm{li}$ & $\begin{array}{l}\text { The freight owners paid the tax } \\
\text { themselves, along with the fees for } \\
\text { the shipowner as wine, writing } \\
\text { the contract, and burning the incense bar }\end{array}$ \\
\hline Carrying pole & $\begin{array}{l}360 \text { wen per dan per day or } \\
\text { per } 80 \mathrm{li}\end{array}$ & Meals compensation: 150 wen per day \\
\hline Mule horse & $\begin{array}{c}300 \text { to } 350 \text { wen per } 2 \text { dan per } \\
\text { day or per } 75 \mathrm{li}\end{array}$ & $\begin{array}{l}\text { Animal food fee and meals } \\
\text { compensation: } 150 \text { wen }\end{array}$ \\
\hline Donkey & $\begin{array}{c}200 \text { to } 300 \text { wen per dan per } \\
\text { day or per } 75 \mathrm{li}\end{array}$ & $\begin{array}{l}\text { Animal foods fee and meals } \\
\text { compensation for donkey owners }\end{array}$ \\
\hline
\end{tabular}

All information are taken from [53].

Second, water resources play an important role in the process of urban and regional sustainable development. Water is the source of life, and any place where human beings live can not survive without sufficient water; the development of a city is no exception. The threat of flood often brings great harm to the development of cities. The floods not only destroy the city itself but also cause economic recessions in the hinterland of the city, and then worsen the environmental support for the existence and development of the city, which seriously restricts the further development of the city. Such problems appeared very prominent in Kaifeng during the Qing Dynasty. The frequent flooding of the Yellow River destroyed many Kaifeng city buildings and traffic arteries and caused the continuous deterioration of the environment in Eastern Henan, with vegetation destruction, ecological imbalance, land desertification, and agricultural production decline, thus accelerating the decline of Kaifeng.

By studying the relations between the rise and fall of Kaifeng and the Grand Canal, we can obtain the following conclusion: Developing transportation; guaranteeing the clear transport of urban goods, personnel, and information; and promoting the development and improvement of urban open economic system and structure are vital to the promotion of a city's development. Simultaneously, consolidating the construction and improvement of water conservancy facilities, protecting the environment, eliminating flooding, and establishing harmonious development between humans and nature is essential to maintaining the sustainable development of a city. 
Nowadays, human beings have entered the 21st century. The development of industry, agriculture, life, and the ecological environment is more dependent on water usage. The water crisis is a major challenge for sustainable development. The progress of science and technology and the development of modern three-dimensional transportation means that inland waterway transportation no longer determines the economic territory and political pattern of a country or region. However, water is still the source of life, and given that the city is the area where residents gather, there must be sufficient water resources and well-functioning water conservancy facilities to form a livable ecological environment by meeting the living needs of the people, the sustainable development of urban industry, and the surrounding agriculture. Therefore, the development of water resources and water conservancy and transportation is still a key factor in the rise and fall of cities and regions. In addition, in recent years, under the influence of global climate change, water resources in many countries have decreased significantly. The tension between supply and demand has become increasingly acute. Some countries have begun to take measures to solve the water crisis. Singapore has tried to solve the water shortage crisis through various ways by managing water resources as the environmental asset of the city and creatively putting forward the ABC plan (active, beautiful, clean waters program) in 2006. "Active" in the name of the project refers to the creation of a vibrant hydrophilic entertainment and community space. "Beautiful" refers to the transformation of concrete canals to integrate with the urban green environment to provide a beautiful waterscape. "Clean" refers to the overall management of water resources and the use of public education to cultivate a more harmonious relationship between people and water to keep water sources clean and improve water quality [54].

Urbanization is a major comprehensive issue that the world is facing, which involves coordinating with the development of the national economy and is related to the sustainable development of reasonable utilization and the long-term protection of resources and the environment [55]. At the same time, rapid urbanization has brought great pressure on resource supply and environmental protection; large-scale urban construction has caused the shortage of water resources in cities among 15 provinces in northern China. Many towns in southern China often have serious water supply issues due to water quality problems [56].

To solve the shortage of water resources in Beijing, Tianjin, Hebei, and other places, as well as provide for the demand for the high-quality development of the Yellow River Basin for water resources, in 2002, the Chinese government began to implement a largescale "South to North Water Diversion" project, which transports water resources from the south to the north through artificial rivers (Figure 8). Interestingly, it can be seen from the picture below that most of the Eastern route of China's South to North water diversion project uses the channel of the original Grand Canal, which also reflects the value and significance of the wisdom of water control and management in ancient China in today's urban and regional sustainable development.

In order to protect water resources, in December 2016, the Chinese government issued the "Opinions on Comprehensively Implementing the River Head System" and issued a notice requiring all regions and departments to seriously implement it by tailoring their policies to each actual local situation. By the end of June 2018, 31 provinces (Autonomous Regions and Municipalities directly under the central government) in China had fully established the River Head System. These provinces have more than 300,000 river heads at the provincial, municipal, county, and township levels (held by the main leaders of the party and government at all levels in China). Twenty-nine provinces have set up more than 760,000 village river heads, fulfilling the "last mile" of the River Head System [57]. In addition, the law of the people's Republic of China on the protection of the Yangtze River came into force on 1 March 2021, which establishes the principle of the sustainable utilization of water resources in river basins [58]. 


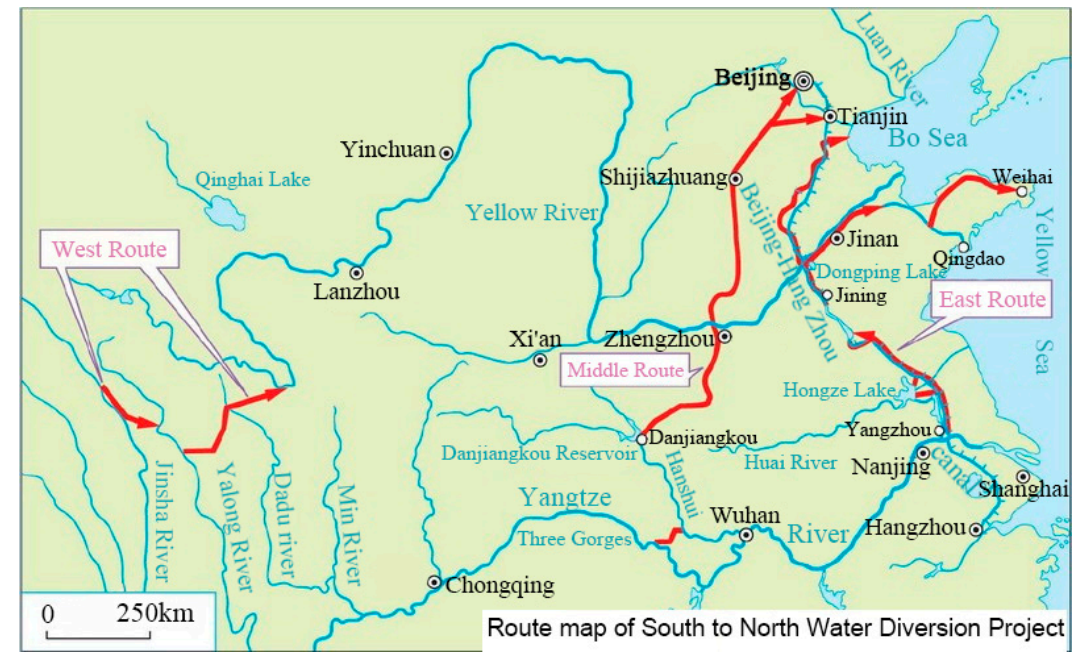

Figure 8. Route map of the South-to-North Water Diversion Project.

In addition, with global warming and the scientific development concept of energy saving and emission reduction, green environmental protection is increasingly popular and water transportation has been paid more and more attention again. Vigorously developing inland water transportation is a response to the need to realize the sustainable development of transportation and the need to build a resource-saving and environmentally friendly society. At present, many local governments in China have put forward plans to restore inland water transportation and canal navigation. In October 2019, the $11.4 \mathrm{~km}$ section of the North Canal from the Beiguan Sluice to the Gantang Sluice in Tongzhou will realize tourism navigation (Figure 9). In May 2020, Tianjin Grand Canal's cultural protection, inheritance, and utilization plan put forward the goal of segmentation of time, sections, and regions for tourism navigation. The $40 \mathrm{~km}$ Beijing Tongzhou section of the Grand Canal will be open to navigation before 1 July 2021, and the Xianghe section of the Grand Canal will be synchronized with the Beijing section for tourism and navigation. Although the restoration of navigation of the Grand Canal reflects the value of cultural tourism, the navigation of the Grand Canal can dredge the whole water system, which is of great significance to the comprehensive utilization of water resources, the construction of ecological civilization, and the sustainable development of cities and regions.

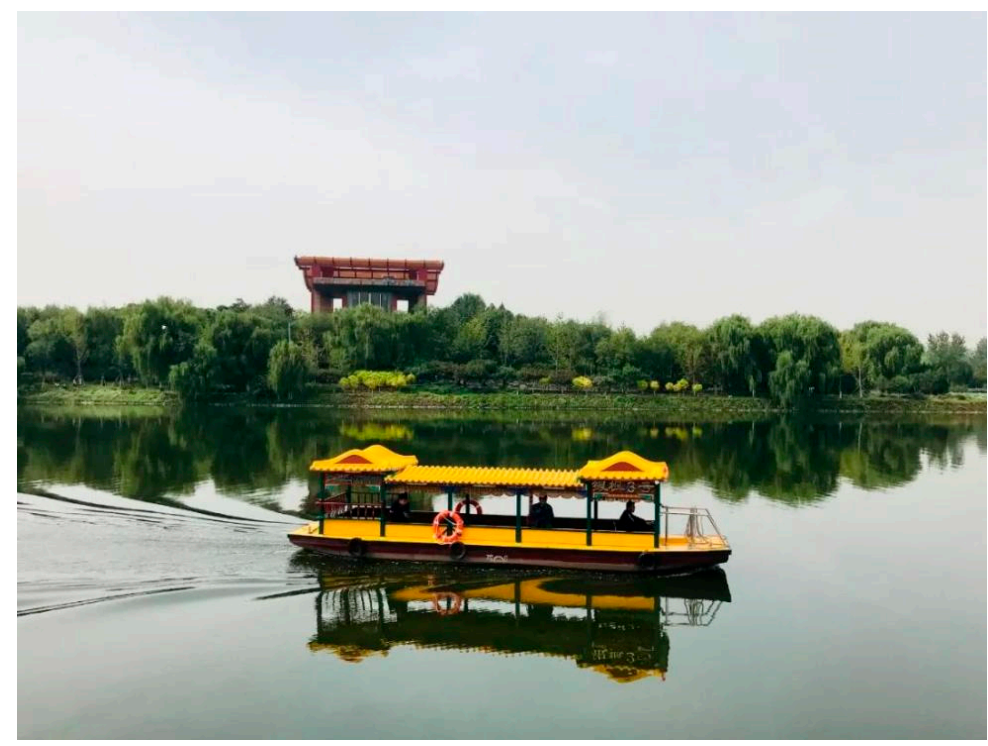

Figure 9. Canal navigation of the North Canal in Beijing at Tongzhou section of the Beiguan sluice en route to the Gantangzha sluice). 
Therefore, this study on the rise and fall of the Grand Canal and Kaifeng can further clarify the evolution of Kaifeng and reveal the characteristics and laws of urban development. On the other hand, it can also help us learn from the experience and lessons of ancient water resources development, utilization, and protection, and provide some reference and inspiration for today's urban and regional sustainable development.

Author Contributions: Conceptualization, W.H.; Formal analysis, W.H. and S.L.; Investigation, M.X.; Resources, M.X.; Supervision, S.L.; Validation, F.T.-H.; Visualization, M.X.; Writing—original draft, W.H.; Writing - review and editing, S.L. and F.T.-H. All authors have read and agreed to the published version of the manuscript.

Funding: Grant in aid for Excellent Young Researcher of the Ministry of Education of Japan (MEXT); research funding project of Neijiang Normal University: local records research and innovation team of Tuojiang River Basin (2019TD04); Sichuan Social Science Foundation of China (Grant No: SC21A008).

Institutional Review Board Statement: Not applicable.

Informed Consent Statement: Not applicable.

Data Availability Statement: This study did not provide any data.

Conflicts of Interest: The authors declare no conflict of interest.

\section{References}

1. Tuan, Y.-F.; Butzer, K.W. Early Hydraulic Civilization in Egypt: A Study in Cultural Ecology. Geogr. Rev. 1977, 67, 369. [CrossRef]

2. Mays, L.W. A very brief history of hydraulic technology during antiquity. Environ. Fluid Mech. 2008, 8, 471-484. [CrossRef]

3. Strouhal, E. Life in Ancient Egypt, 1st ed.; Cambridge University Press: London, UK, 1992.

4. Altaweel, M. Southern Mesopotamia: Water and the rise of urbanism. Wiley Interdiscip. Rev. Water 2019, 4. [CrossRef]

5. Schrakamp, I. Irrigation in 3rd Millennium Southern Mesopotamia: Cuneiform Evidence from the Early Dynastic IIIb City-State of Lagash (2475-2315 BC). In Water Management in Ancient Civilizations; Berking, J., Ed.; Topoi/Exzellenzcluster Topoi der Freien, Universität Berlin und der Humboldt-Universität zu Berlin: Berlin, Germany, 2018; pp. 119-197.

6. Adamo, N.; Al-Ansari, N. The Sumerians and the Akkadians: The forerunners of the first civilization (2900-2003BC). J. Earth Sci. Geotech. Eng. 2020, 10, 17-39.

7. Singh, P.K.; Dey, P.; Jain, S.K.; Mujumdar, P.P. Hydrology and water resources management in ancient India. Hydrol. Earth Syst. Sci. 2020, 24, 4691-4707. [CrossRef]

8. Guo, R. Rivers Cyclical Floods and Civilizations. Experiment Findings. 2016. Available online: https:/ /www.researchgate.net/ publication/305639882_Rivers_Cyclical_Floods_and_Civilizations (accessed on 2 July 2021).

9. Jianjun, S. Stories of Chinese General History; Jilin Literature and History Publishing House: Changchun, China, 2017; pp. $233-237$.

10. Wei, G. Grand Canal and TongZhou Ancient City; Beijing Publishing House: Beijing, China, 2018; p. 14.

11. Guotai, J. Wang Jingfen. China Travel Guide; China Travel Press: Beijing, China, 1988; p. 391.

12. Li, T.; Junzhe, Z.; Zhuangxing, Z. Xiangfu County Annals; Zhongzhou Ancient Books Publishing House: Zhengzhou, China, 2019.

13. Zhang, M. History of Kaifeng Construction. In The Record of Kaifeng Government; 1695; Volume 2.

14. Fang, Z. Ancient Capital of China; China Business Press: Beijing, China, 2015; p. 23.

15. Ouyang, X.; Song, Q. Biography of Cui. In New History of the Tang Dynasty; 1060; Volume 176.

16. Yuan, Z. Written Report of Tongzhou for Equal Landship System. In Reeks of Yuan Zhen; Zhonghua Book Company: Beijing, China, 1982; Volume 38.

17. Tuotuo. Records of Rivers and Canals IV. In History of the Song Dynasty; 960; Volume 94.

18. Ouyang, X.; Song, Q. Records-Section 43, Consumer Goods-III. In New History of the Tang Dynasty; 1060; Volume 59.

19. Xu, J. Additional Discussion on Conditions of Establishing Big Ancient Capital of China. Symp. Hist. Geogr. China 1994, 3, 63-71.

20. Records of the Emperor Yangdi of the Sui Dynasty. In History of Sui Dynasty; Zhonghua Book Company: Beijing, China, 1973; Volume 3.

21. Li, J. Through ships on Bianhe River. In Collected Tang Poems; 1990; Volume 508.

22. Wang, J. Things on roads in Bianzhou. In Collected Tang Poems; 1990; Volume 299.

23. Ouyang, X. Biography of Quan Deyu. In New History of the Tang Dynasty; Zhonghua Book Company: Beijing, China, 1975; Volume 165.

24. Liu, K. Records of Tingbi by office clerk of Bianzhou. In Complete Literature Works of Tang Dynasty; Volume 740.

25. Shi, N. Geographical factors of establishing capital of ancient China. In Chinese Ancient Capital Society, Study on Chinese Ancient Capital, 2nd ed.; Zhejiang Renmin Press: Hangzhou, China, 1986; p. 5.

26. He, Y. Urban Development and Social Change of Modern China (1840-1949); Science Press: Beijing, China, 2004.

27. N.A.N.A. Erie Britain, Gui Lisheng translated; Urban Economics; China Building Industry Press: Beijing, China, 1987.

28. Robert, H. A Cycle of economic change in imperial China: Coal and iron in Northeast China, 750-1350. J. Econ. Soc. Hist. Orient 1967, 10, 102-159. [CrossRef] 
29. Lu, S.; Zhang, X.; Wang, J.; Pei, L. Impacts of different media on constructed wetlands for rural household sewage treatment. J. Clean. Prod. 2016, 127, 325-330. [CrossRef]

30. Wang, P. Inner and outer city walls. In Social Backgrounds of the Five Dynasties; 1987; Volume 26.

31. Fan, Z. Memorandum in East House; Zhonghua Book Coompany: Beijing, China, 1980.

32. Tuotuo. Record of Consumer Goods-Volume 1. In History of the Song Dynasty; Volume 175.

33. Tuotuo. Records of Rivers and Canals III. In History of the Song Dynasty; 960; Volume 93.

34. Zhang, F. On advantages and disadvantages of Bianhe River. In Lequan Collections; Volume 27.

35. Yu, F. The Compilation of Social Backgrounds of the Song Dynasty; Volume 13, p. 16.

36. Gu, Y. Kaifeng. In Records of Capitals of Past Dynasties; Volume 16.

37. Kaifeng Song Dynasty City Archaeological Team. Brief Report on Preliminary Survey and Trial Digging of Inner City of Dongjing in the Northern Song Dynasty. Cult. Relic. 1996, 5.

38. Fu, C. Development History of Cities Along Canal in Ancient China; Renmin Press: Beijing, China, 1986.

39. Zhou, B.Z. Study on Dongjing of the Song Dynasty; Henan University Press: Zhengzhou, China, 1992.

40. Meng, Y. Beautiful Dreams of Dongjing, Prologue. In Continued Chronicle of History as a Mirror; Commercial Press: Beijing, China, 1922; Volume 38.

41. Lu, S.; Zhang, X.; Zheng, Z.; Skitmore, M. The energy-food-water nexus: Water footprint of Henan-Hubei-Hunan in China. Renew. Sustain. Energy Rev. 2020, 133, 110417.

42. Shiba, Y. Study on History of Commerce of the Song Dynasty; Daohe Press: Taibei, Taiwan, 1997.

43. Miyazaki, I. Modern Times of Japan, Selected Translation on Works of Chinese History for Study of Japanese Scholars; Zhonghua Book Company: Beijing, China, 1992.

44. Skinner, G.W. Study on Cities of China During the Later Period of Feudal Society; Jilin Education Press: Changchun, China, 1991.

45. Sun, F. Zhi Guan Fen Ji. In Complete Library in the Four Branches of Literature; Commercial Press: Shanghai, China, 1934.

46. Zhao, Q. Study on Ecological Environment Evolution of Bianhe River and Its Impact on Riverside Social Economy and Culture; Henan University: Zhengzhou, China, 2019.

47. Li, L. Records of Relics in Bianjing; Zhonghua Book Company: Beijing, China, 1999; p. 82.

48. Liu, H. Archaeological study on forms of Bianhe River in the Tang and Song Dynasties. Huaxia Archaeol. 2016, 4, $108-117$.

49. Tuotuo. Biography of Zhang Fangping. In History of the Song Dynasty; Volume 289.

50. Naito, K. The General Sense of Tang and Song Dynasities. Hist. Geogr. Jpn. 1910, 9.

51. Li, H. Research summary on the China-Japan sense of Tang and Song Reform in the 20th century. Res. Hist. Theory 2003, 4, 87-95.

52. Qian, M. Neo-Confucianism and Art: Research Collections of History of Song Dynasty; Taiwan Book House: Taibei, Taiwan, 1974.

53. Inland Communications in China. J. China Branch R. Asiat. Soc. 1898, 28.

54. Chuanglin, F. Important progress and prospects of China's urbanization and urban agglomeration in the past 40 years of reform and opening Up. Econ. Geogr. 2018, 38, 1-9.

55. Lu, S.; Li, J.; Xiao, B.; Guo, M. Analysis of standard accounting method of economic compensation for ecological pollution in watershed. Sci. Total. Environ. 2020, 737, 138157. [CrossRef]

56. Lu, S.; Bai, X.; Li, W.; Wang, N. Impacts of climate change on water resources and grain production. Technol. Forecast. Soc. Change 2019, 143, 76-84. [CrossRef]

57. Newspaper of People's Liberation Army. 3rd Version. Available online: https://cpcchina.chinadaily.com.cn/2011-10/19 / content_13994372.htm (accessed on 18 July 2018).

58. Wang, W.; Chen, G. Sustainable utilization of river basin water resources-Explanation on the legislative principles of the Yangtze River Protection Law. J. Nanjing Univ. Technol. 2019, 18, 1-15. 